\title{
Carbon assimilation and phytoplankton growth rates across the trophic spectrum: an application of the chlorophyll labelling technique
}

\author{
Giuseppe MORABITO*, Waleed HAMZA ${ }^{1)}$ and Delio RUGGIU \\ CNR Istituto per lo Studio degli Ecosistemi, Largo V. Tonolli 50, 28922 Verbania Pallanza, Italy \\ ${ }^{1)}$ Biology Department, Faculty of Science United Arab Emirates University, P.O. Box 17551-Al-Ain, UAE \\ *e-mail corresponding author: g.morabito@ise.cnr.it
}

\begin{abstract}
The chlorophyll labelling technique has been acknowledged to be a useful method for measuring phytoplankton growth rates while avoiding some of the problems involved in calculating growth rates derived from the ${ }^{14} \mathrm{C}$ fixation rates. The results presented here are of experiments comparing phytoplankton growth rates during the summer season in three subalpine Italian lakes: Lago Maggiore, the second largest lake in Italy, and two smaller lakes, Lake Mergozzo and Lake Varese, both included in the Lago Maggiore drainage basin. The three lakes have different morphometric, physico-chemical and biological features. The first goal was to compare two different methods of estimating phytoplankton growth rates starting from ${ }^{14} \mathrm{C}$ assimilation. The second goal of our experiments was to test the hypothesis that growth rates can be quite different across the trophic spectrum, due to the ecophysiological and morphological features of the phytoplankton assemblages. In particular, algal cell size should decrease from eutrophic to oligotrophic systems and growth rates should follow the opposite trend, as they are inversely scaled to the cell size. Two basic conclusions can be drawn. The first is that, in spite of some drawbacks still affecting the use of the chlorophyll labelling technique, this appears to be one of the most promising methods for estimating the growth rates of phytoplankton in situ. The second conclusion is that this method, coupled with information on some algal morphological parameters, can provide useful indications about the functional properties of phytoplankton assemblages living in diverse lacustrine environments.
\end{abstract}

Key words: primary productivity, chlorophyll labelling, phytoplankton growth rates, species assemblage structure

\section{INTRODUCTION}

The metabolism of a lake system is closely related to ways of nutrient replenishment and the amount of nutrient supply, which largely determine its trophic status. Although the uptake capacity of phytoplankton may exceed nutrient requirements for growth even in oligotrophic systems, growth rates show a wide range of amplitude. They usually mirror the ecophysiological features of the phytoplankton assemblage (Reynolds 1997), whose composition is, in turn, variable across the trophic spectrum.

In particular, the physiology of the algal cell is strictly dependent on its size: cell size is a key morphometric parameter, because many metabolic processes are scaled with the size of the cells (Reynolds 1997). In terms of photosynthetic efficiency, for instance, it is known that an increase in cell radius decreases the average specific absorption coefficient of chlorophyll a (Raven \& Kübler 2002), making smaller algae more efficient. In terms of ecosystem functioning, the accepted theory (see also Harris 1986, 1994) postulates that, when nutrients are scarce, phytoplankton is dominated by small algae with high nutrient affinity, and that the entire plankton community is driven by a tight coupling between grazing and nutrient regeneration. On the other hand, when the nutrient load increases, the phytoplankton community will change in composition towards species with a different metabolism, i.e. lower nutrient affinity, higher nutrient demands and larger cell volumes.

Therefore, estimation of phytoplankton growth rate, coupled with analysis of phytoplankton assemblage structure, can provide a number of useful indications on the functioning of an aquatic ecosystem, because the growth rate is related to the carbon pathways within the food web, to the utilisation of nutrients and to the export of biomass to other trophic levels. However, despite the need for growth rate measurements, there have been few field studies providing these data, mostly because the measure of growth rate in situ involves serious methodological difficulties.

We used different approaches to evaluate phytoplankton growth rate. A common procedure for obtaining the growth rate is to divide the photosynthetic ${ }^{14} \mathrm{C}$ uptake by the carbon biomass (Steeman-Nielsen 1952). However, a distinction between net and gross production from rates of ${ }^{14} \mathrm{C}$ uptake cannot be achieved with greater precision than $50 \%$, as has been thoroughly reviewed by Peterson (1980) and Williams (1993). The variability of the carbon-to-chlorophyll- $a$ ratio can add a further source of bias (Riemann et al. 1989). However, Redalje \& Laws (1981) suggested a direct method for measuring growth rates of natural phytoplankton populations, which allows simultaneous measurements of the growth rate and of the carbon specific biomass without the need to know the carbon-to-chlorophyll- $a$ ratio. The 


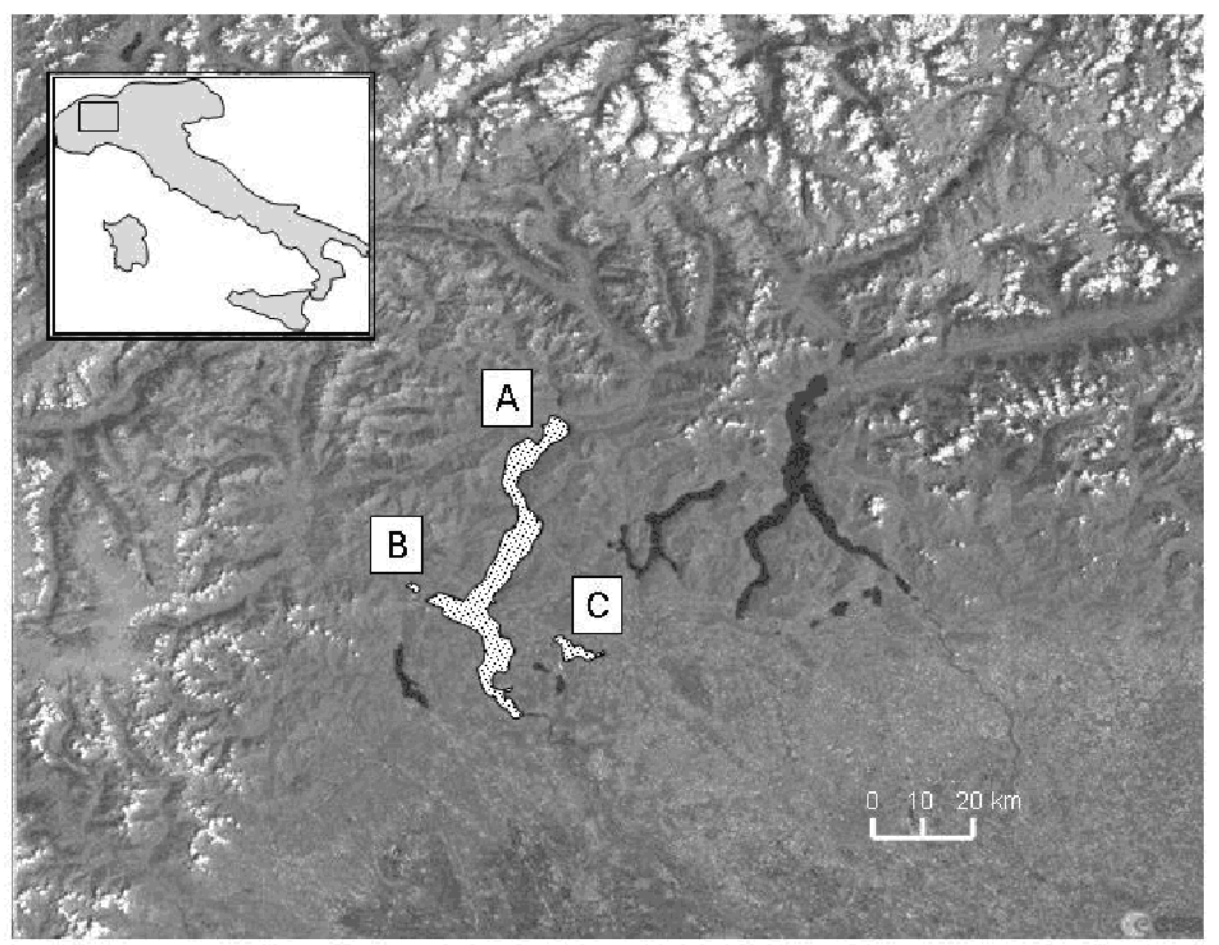

Fig. 1. Lakes Maggiore (A) Mergozzo (B) and Varese (C) shown as shaded areas in a satellite image (source: European Space Agency).

Tab. 1. Main morphometric parameters of the three lakes.

\begin{tabular}{lccc}
\hline & L. Maggiore & L. Mergozzo & L. Varese \\
\hline Altitude $(\mathrm{m}$ a.s.l.) & 194 & 194 & 238 \\
Drainage basin area $\left(\mathrm{km}^{2}\right)$ & 37500 & 10.4 & 1.5 \\
Volume $\left(\mathrm{m}^{3} 10^{6}\right)$ & 6599 & 0.083 & 0.16 \\
Area $\left(\mathrm{km}^{2}\right)$ & 212 & 1.82 & 14.95 \\
Max depth $(\mathrm{m})$ & 370 & 73 & 26 \\
Mean depth $(\mathrm{m})$ & 177.5 & 45.4 & 10.7 \\
Turn over time (y) & 4.1 & 6 & 1.8 \\
\hline
\end{tabular}

method is based on determination of the incorporation rate of ${ }^{14} \mathrm{C}$ into chlorophyll- $a$, and takes advantage of the fact that chlorophyll is a stable end product in carbon assimilation and that apparently little carbon is respired from the synthesised chlorophyll- $a$ (Hein \& Riemann 1995).

In this study, we used the chlorophyll labelling technique to evaluate the carbon assimilation of summer phytoplankton assemblages in three North Italian lakes: the oligotrophic Lake Mergozzo, the oligo-mesotrophic Lago Maggiore and the eutrophic Lake Varese. The main goals of the research were i) to compare two different methods of estimating phytoplankton growth rates starting from ${ }^{14} \mathrm{C}$ assimilation, and ii) to evaluate the validity of chlorophyll labelling as a direct method of estimating algal growth rates in different trophic conditions. In discussing the results, we will take into account the variability of the morphometric features of phytoplankton cells across the trophic spectrum.

\section{THE LAKES}

We chose as experimental sites three North Italian lakes (Fig. 1) located in the western area of the subalpine lake district. The smaller two, lakes Varese and Mergozzo, are included in the catchment area of Lago Maggiore. Table 1 lists the main morphometric features of the three basins, and table 2 shows their basic chemistry on the dates of the individual experiments.

These three lakes were chosen to compare the results in lacustrine environments characterised by different trophic states, morphology and morphometry and, presumably, by different phytoplankton assemblages. We made two experiments per lake during summer, starting on June 22 and finishing on July 7, with the sampling periodicity reported in table 2 . A short description of the lakes' history and a summary of earlier studies follows:

I. Lago Maggiore, the second largest Italian subalpine lake (Fig. 1A) is oligotrophic by nature, as testified 
Tab. 2. Basic chemistry at the sampling dates. Data are integrated values in the euphotic zone. N.D. = not detectable.

\begin{tabular}{lccccccc}
\hline & $\mathrm{pH}$ & $\begin{array}{c}\mathrm{N}^{-\mathrm{NO}_{3}} \\
\left(\mu \mathrm{g} \mathrm{l}^{-1}\right)\end{array}$ & $\begin{array}{c}\mathrm{N}^{-\mathrm{NH}_{4}} \\
\left(\mu \mathrm{g} \mathrm{l}^{-1}\right)\end{array}$ & $\begin{array}{c}\mathrm{P}^{-\mathrm{PO}_{4}} \\
\left(\mu \mathrm{g} \mathrm{l}^{-1}\right)\end{array}$ & $\begin{array}{c}\mathrm{TP} \\
\left(\mu \mathrm{g} \mathrm{l}^{-1}\right)\end{array}$ & $\begin{array}{c}\mathrm{Si} \\
\left(\mathrm{mg} \mathrm{l}^{-1}\right)\end{array}$ \\
\hline L. Mergozzo & Jun, 23 & 7.22 & 630 & 65 & 3 & 9 & 1.14 \\
& Jun, 29 & 7.21 & 623 & 52 & 4 & 10 & 1.03 \\
\multirow{4}{*}{ L. Varese } & Jun, 30 & 8.71 & 40 & 119 & 7 & 28 & 0.67 \\
& Jul, 05 & 8.76 & 25 & 160 & 7 & 34 & 0.83 \\
& Jun, 22 & 7.96 & 715 & N.D. & 2 & 7 & 0.5 \\
& Jul, 07 & 7.91 & 706 & N.D. & 3 & 10 & 0.8 \\
\hline
\end{tabular}

by early limnological studies (Monti 1929; Baldi 1949; Vollenweider 1965) and by the analysis of the sedimentary pigments (Guilizzoni et al. 1983; Marchetto et al. 2000). The eutrophication process started in the 1960s and the lake reached a trophic state close to eutrophy in the late 1970s ( $\sim 30 \mu \mathrm{g} \mathrm{l}^{-1}$; Mosello \& Ruggiu 1985). Since that time, the $P$ loads have been gradually reduced. As a result, the values of TP at winter mixing gradually decreased, to values around $10 \mu \mathrm{g} \mathrm{l}^{-1}$ in the last few years (Calderoni et al. 1997). Many papers document the slow reversal of the trophic state of Lago Maggiore. Some major biological changes have occurred since 1987-88 (Manca et al. 1992; Ruggiu 1993), and notable changes have also been recorded in the structure of the phytoplankton assemblages with oligotrophication (Ruggiu et al. 1998). Among the most important of these is the remarkable decrease of the average cell size due to increased importance of the smaller sized phytoplankters.

II. Lake Mergozzo (Fig. 1B) is a small lake that was separated from Lago Maggiore by the alluvial deposits of the River Toce five-six centuries ago. From the late sixties the lake began to undergo a process of cultural eutrophication, with the occurrence of Planktothrix blooms and hypolimnetic oxygen depletion being recorded in the period 1969-1970 (Ruggiu \& Saraceni 1972). As the result of a sewage diversion scheme, the in-lake phosphorus started to decrease from the late 1980s, following a trend similar to that recorded in Lago Maggiore. The present TP concentrations at winter mixing are close to $4-5 \mu \mathrm{g} \mathrm{l}^{-1}$. Phytoplankton studies in Lake Mergozzo are few and mainly cover the period of maximum eutrophication (1970-1980; see Zutshi 1976); in fact, information on the evolution of phytoplankton biota in the last two decades is virtually absent.

III. Lake Varese (Fig. 1C) has a tendency to high production because of its morphometric features and the calcareous nature of its basin. The lake was already eutrophic at the beginning of last century (Guilizzoni et al. 1983), and the eutrophication process accelerated greatly in the 1950s. Many studies testified to the worsening of the water quality and its effects on the biotic communities (Bonomi 1962, 1966; Tonolli \& Bonomi 1965). In the late 1960s work began on the construction of a ring collector pipe designed to deviate the effluents to a treatment plant. However, it was not until 1987 that the plant was fully operational. Phytoplankton studies in
Lake Varese were carried out only occasionally. The first detailed analysis dates back to 1979 (Ruggiu et al. 1981). The authors recorded high values of productivity (550 $\mathrm{g} \mathrm{C} \mathrm{m}^{-2}$ as average annual productivity) and nutrient concentration (more than $400 \mu \mathrm{g} \mathrm{l}^{-1} \mathrm{TP}$ at spring overturn) and summer blooms of Planktothrix rubescens and Microcystis aeruginosa. A further comprehensive study, carried out about ten years later (Mosello et al. 1991), showed that, despite the effluent diversion, the eutrophication process was not showing any sign of reversion, and indicated that a considerable release of nutrients from the bottom sediments was affecting the lake. Some unpublished data collected during the last decade on hydrochemistry and phytoplankton also indicate that the trophic conditions had not improved significantly.

\section{METHODS}

We carried out two experiments in summer (JuneJuly) in each of the three lakes, with an interval of one to two weeks (Tab. 2). Usually we took five samples to measure primary productivity, at depths corresponding to specific surface PAR attenuation (100, 50, 25, 10 and 1\%).

Underwater PAR was measured with a Li-Cor radiometer (Li-250, coupled with an underwater quantum cosine sensor Li-192 SB).

Duplicate glass bottles (about $300 \mathrm{ml}$ ), inoculated with $\mathrm{NaH}^{14} \mathrm{CO}_{3}(5 \mu \mathrm{Ci})$, were suspended in situ for about 4 hours around noon to measure productivity and chlorophyll labelling. A blank radioactive sample was prepared by inoculation of the same amount of $\mathrm{NaH}^{14} \mathrm{CO}_{3}$ into a dark bottle, which was processed, without incubation, like the in situ suspended bottles. After incubation, a $30 \mathrm{ml}$ subsample was filtered through $0.2 \mu \mathrm{m}$ Nucleopore filters to measure the POC labelling, and the remaining sample (about $250 \mathrm{ml}$ ) was filtered on GF/C glass fibre filters to estimate chlorophyll- $a$ concentration and chlorophyll specific labelling. After $90 \%$ acetone extraction, chlorophyll concentrations were determined spectrophotometrically. The acetone was then evaporated under vacuum, the concentrated pigment extract (about $2 \mathrm{ml}$ ) poured into a liquid scintillation vial and the activity of the sample determined.

Chlorophyll specific activity and growth rates were finally calculated by the method of Redalje \& Laws (1981) and Redalje (1993). This method assumes that, after a sufficiently long incubation, the specific activity 


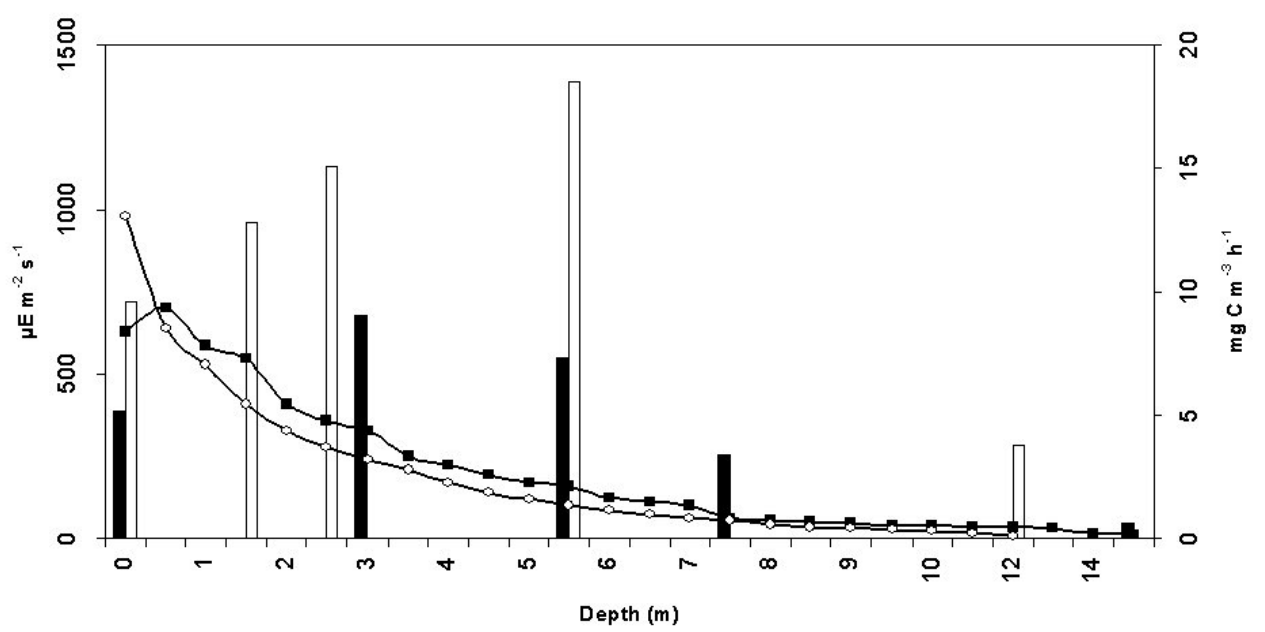

Fig. 2. Vertical profiles of carbon assimilation (bars) and PAR (lines) on the experimental dates in Lago Maggiore: black bars and squares = Jun, $22\left(\mathrm{~K}_{\mathrm{d}}=0.28\right)$; white bars and circles = Jul, $07\left(\mathrm{~K}_{\mathrm{d}}=0.35\right)$.

of the chlorophyll- $a$ carbon will become equal to that of the total phytoplankton carbon pool. The parameter derived is a ratio of the mass of $\mathrm{C}$ in the isolated chlorophyll- $a$ to the ${ }^{14} \mathrm{C}$ activity contained in the isolated chl- $a$.

Phytoplankton determinations were carried out on subsamples preserved in acetic Lugol's solution; algal cells (including ultraplankton cells of about 1-2 $\mu \mathrm{m}$ diameter) were counted on a Zeiss Axiovert 10 microscope, following Lund et al. (1958), until 400 cells for the most important species were counted. The phytoplankton countings were always performed on integrated samples from the euphotic zone. Because the colonial species were counted as number of colonies and not as number of cells, it was not possible to obtain a direct measure of the phytoplankton biovolume. Therefore, phytoplankton assemblage biovolume was estimated from chlorophyll values, using the linear regression equation reported below, derived from a five year set of data from Lago Maggiore (Morabito, unpublished data):

$$
\begin{gathered}
B V=9.655+340.92 \times \text { Chl }-a \\
(\mathrm{n}=103 ; r=0.818: p<0.001)
\end{gathered}
$$

where Chl- $a$ and $B V$ are chlorophyll- $a$ concentration and phytoplankton biovolume, both estimated as integrated values in the euphotic zone. The application of this regression to Lake Varese data might underestimate the phytoplankton biovolume, as in this lake the algae are on average larger than in Lago Maggiore. However, we have to take account of the fact that the regression line was drawn using data collected in different years and seasons, so that the risk outlined above will probably be reduced.

Because the specific algal volumes were not calculated by direct measurement during this study, an average surface area-to-volume ratio of the whole phytoplankton assemblage was estimated for each experiment, using the ratios found in literature for the most widespread species (Reynolds 1984 and references therein), weighted for the density of the dominant species in our lakes. For each experiment we included in the estimate most of the species present (contributing to more than $95 \%$ of the total biomass).

The chemical parameters were determined on integrated water samples collected in the euphotic zone. The analyses were carried out in the chemical laboratory of the Istituto per lo Studio degli Ecosistemi (Pallanza), following the methods reported in Mosello \& Ruggiu (1985).

\section{RESULTS}

\subsection{Basic chemistry on the sampling dates}

Basic chemical features showed an insignificant variability between the two experiments in all three lakes. So, at least from the chemical point of view, the two experiments can be viewed as replicates. The values of $\mathrm{pH}$ and of the main algal nutrients at the experimental sites and periods are listed in table 2. Lakes Maggiore and Mergozzo both showed similar concentrations of nitrate nitrogen, and of inorganic and total phosphorus, but we measured a higher silica concentration in Lake Mergozzo in both samplings. In Lake Varese nitrate nitrogen was much lower than in the other two lakes, whereas ammonium and TP values almost four times higher were recorded. Silica concentration in Lake Varese was intermediate among the three lakes.

\subsection{Phytoplankton productivity and PAR attenuation 4.2.1. Lago Maggiore}

We carried out two experiments in Lago Maggiore, on June 22 and on July 7. In both experiments the euphotic zone extended below $10 \mathrm{~m}$ depth, reaching $14 \mathrm{~m}$ in June and $12 \mathrm{~m}$ in July (Fig. 2). The increase of incident light just below the surface and the distortion of the profile are probably due to the windy weather and sur- 

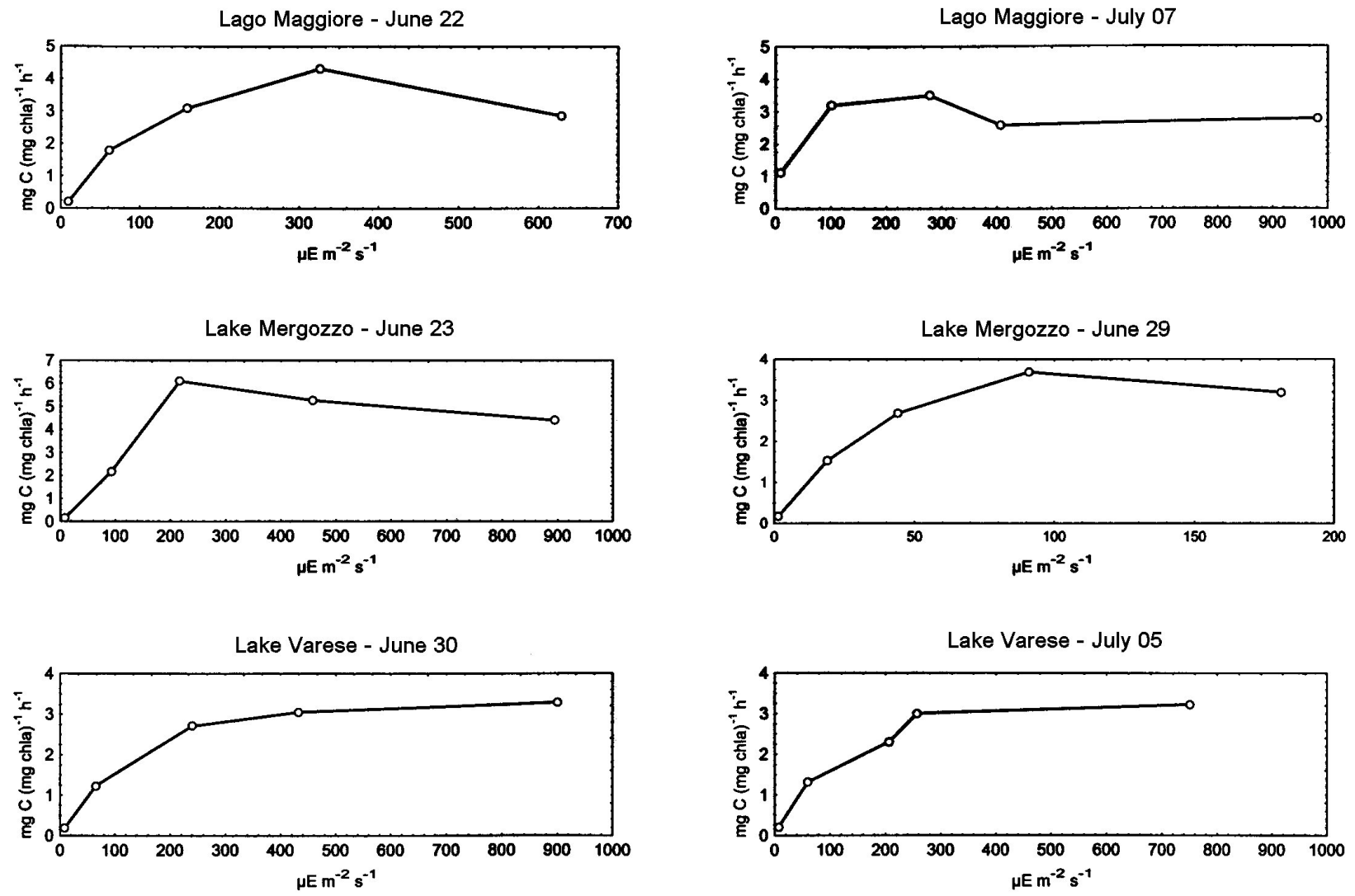

Fig. 3. Chlorophyll specific rates versus light in lakes Maggiore (upper panels), Mergozzo (middle panels) and Varese (lower panels).

face waves occurring at the time of measurement. In the first experiment the vertical profile of carbon assimilation showed a subsurface maximum at $3 \mathrm{~m}$ depth, corresponding to $50 \%$ of surface PAR, whereas in July the maximum assimilation was recorded at $5.5 \mathrm{~m}$, corresponding to $25 \%$ of surface PAR. A higher chlorophyll concentration in July $\left(4.65 \mu \mathrm{g} \mathrm{l}^{-1}\right.$, against $2.25 \mu \mathrm{g} \mathrm{l}^{-1}$ in June, as weighted average in the euphotic zone) can explain the different amount of ${ }^{14} \mathrm{C}$ assimilated.

The profile of the chlorophyll specific rates (photosynthetic rates) versus light shows a slight surface inhibition in both experiments (Fig. 3).

\subsubsection{Lake Mergozzo}

The experiments in Lake Mergozzo were both carried out in June (23 and 29). The PAR attenuation was again low in this lake, where the euphotic depth reached $15 \mathrm{~m}$ in the first experiment and $18 \mathrm{~m}$ in the second (Fig. 4). During the second experiment, because of cloud cover, the amount of incident PAR was only about $1 / 5$ of that recorded during the first experiment. This finding could account for the difference between the two vertical profiles of carbon assimilation. In the second experiment we observed a surface maximum, probably due to a reduced inhibitory effect of the low incident PAR, and a gradual decline towards the bottom of the photic zone. In contrast, the profile recorded on June 23 displayed an assimilation peak at $5 \mathrm{~m}$ (25\% of surface PAR). Average chlorophyll- $a$ concentration in the euphotic zone was similar in both experiments (3.31 and $3.42 \mu \mathrm{g} \mathrm{l}^{-1}$ ).

The photosynthetic rates $v s$ light profiles of Lake Mergozzo (Fig. 3) indicate a slight surface inhibition, as already recorded in Lago Maggiore.

\subsubsection{Lake Varese}

The vertical profiles of PAR extinction and carbon assimilation (Fig. 5) reflected the high trophic level of Lake Varese. In both experiments we recorded a euphotic zone not deeper than $3.5 \mathrm{~m}$, and a steep PAR attenuation, with $90 \%$ of surface light absorbed within the first two meters of the water column. Productivity profiles were typical of eutrophic lakes, with a single, very high peak located close to the surface. A dissimilar amount of underwater PAR was perhaps responsible for the quite different carbon assimilation rates recorded at the peak value in the two experiments. This result suggests a light limitation in the water column of Lake Varese. A deep chlorophyll peak was recorded on July 7 (68.7 $\mu \mathrm{g} \mathrm{l}^{-1}$ at $3.5 \mathrm{~m}$, lower limit of the euphotic zone). Despite the shape of the vertical assimilation profile, the photosynthetic rates (Fig. 3) indicate that the algae are 


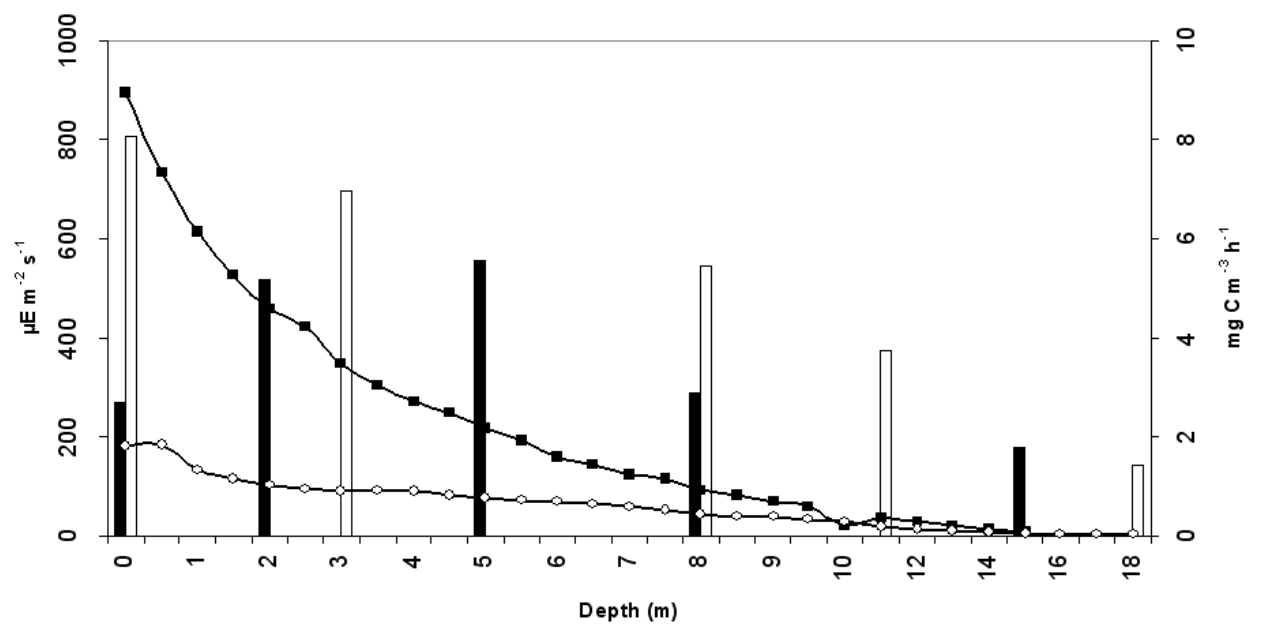

Fig. 4. Vertical profiles of carbon assimilation (bars) and PAR (lines) on the experimental dates in Lake Mergozzo: black bars and squares = Jun, $23\left(\mathrm{~K}_{\mathrm{d}}=0.30\right)$; white bars and circles = Jun, $29\left(\mathrm{~K}_{\mathrm{d}}=0.25\right)$.

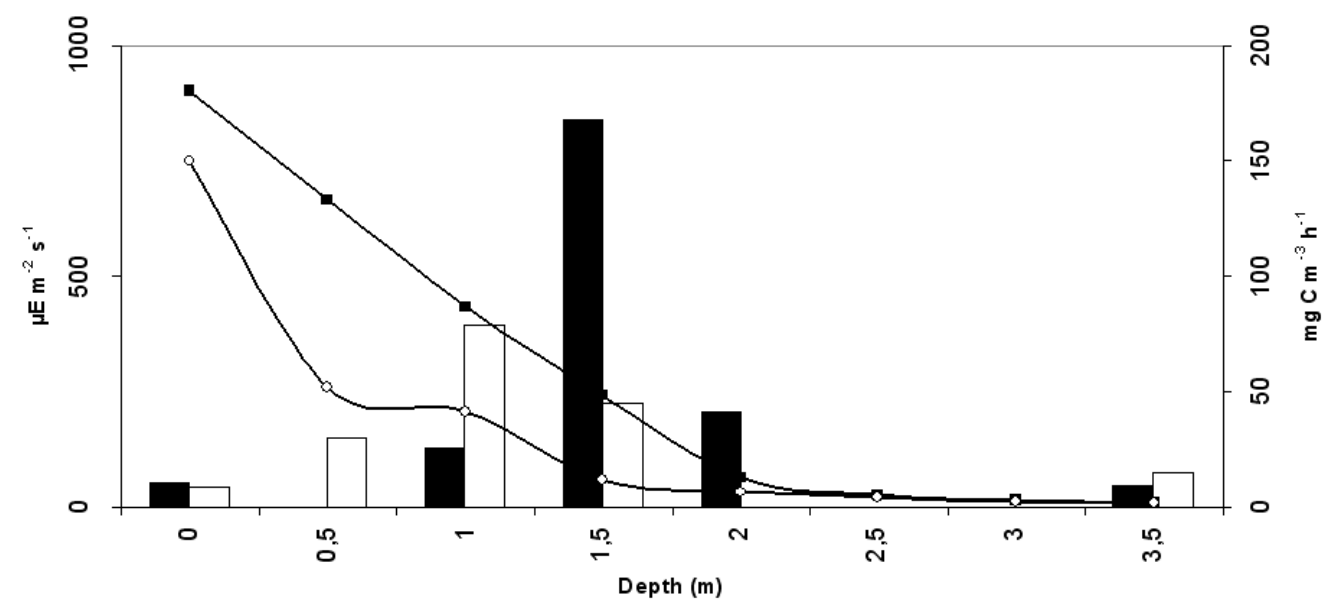

Fig. 5. Vertical profiles of carbon assimilation (bars) and PAR (lines) on the experimental dates in Lake Varese: black bars and squares = Jun, $30\left(\mathrm{~K}_{\mathrm{d}}=1.47\right)$; white bars and circles = Jul, $05\left(\mathrm{~K}_{\mathrm{d}}=1.31\right)$.

well adapted to high light intensities: we did not observe any light inhibition in either experiment.

\subsection{Phytoplankton assemblages}

The three lakes showed quite different phytoplankton assemblages (Tab. 3), but there were no significant modifications in any lake from the first to the second experiment, probably because of the short time intervals. This finding supports the hypothesis that differences between both productivity and growth rates could be due to the variability of the light climate, rather than to changes in the water chemistry or the phytoplankton assemblages.

In Lago Maggiore, the dominant phytoplankton species were Cyclotella comensis, Tabellaria flocculosa, Fragilaria crotonensis, Chrysochromulina parva, Uroglena americana and Ochromonas sp. In the second experiment a significant increase of Cyclotella comensis and Chrysochromulina parva was observed, whereas Uroglena americana and Ochromonas sp. declined.

Asterionella formosa and Sphaerocystis schroeteri dominated the assemblage of Lake Mergozzo in both experiments, with a slight decline from the first to the second experiment. Chrysochromulina parva was also important in this lake.

Uroglena americana and Ceratium hirundinella were the dominant species in Lake Varese on the sampling dates. Dinobryon sociale and Rhodomonas minuta reached quite high densities, with Chrysochromulina parva and Chlamydomonas sp. showing some degree of importance. All the species showed a decline between the two experimental dates.

\subsection{Growth rates}

According to Redalje \& Laws (1981), the most important constraint, when using the chlorophyll labelling 
Tab. 3. Phytoplankton assemblages at the experimental dates in the three lakes. Data as cells or colonies $\mathrm{ml}^{-1}$. SA/V Published = data from Reynolds (1984); SA/V Measured = directly estimated in 2003 from Lago Maggiore phytoplankton.

\begin{tabular}{|c|c|c|c|c|c|c|c|c|}
\hline & SA & $\mathrm{A} / \mathrm{V}$ & L. Me & gozzo & L. I & rese & L. M & giore \\
\hline & Published & Measured & Jun, 26 & Jun, 29 & Jun, 30 & Jul, 05 & Jun, 22 & Jul, 07 \\
\hline Cyanoprokaryota & & & & & & & & \\
\hline Merismopedia punctata (col.) & & & 24 & & & & & \\
\hline Microcystis sp. (col.) & 0.03 & 0.07 & 9 & 1 & & & & \\
\hline Anabaena solitaria (fil.) & 1.03 & & 3 & 3 & 21 & 27 & & \\
\hline Planktothrix rubescens (fil.) & 0.52 & 0.43 & 6 & 5 & & & 9 & 6 \\
\hline Microcystis viridis (col.) & & & & & 18 & 24 & & \\
\hline Microcystis aeruginosa (col.) & & & & & 9 & 9 & & \\
\hline Aphanizomenon flos-aquae (fil.) & 1.62 & 0.50 & & & 48 & 21 & & \\
\hline Bacillariophyceae & & & & & & & & \\
\hline Asterionella formosa & 1.16 & & 2242 & 1347 & & & & \\
\hline Cyclotella comensis & 0.5 & 0.11 & & & & & 120 & 534 \\
\hline Tabellaria flocculosa & 0.71 & 0.70 & & & & & 147 & 72 \\
\hline Fragilaria crotonensis & 1.5 & 1.11 & & & & & 171 & 114 \\
\hline Chryso-/Haptophyceae & & & & & & & & \\
\hline Mallomonas tonsurata & & & 30 & 30 & & & & \\
\hline Mallomonas sp. & & & & & & 21 & & \\
\hline Chrysochromulina parva & 1.30 & 1.47 & 162 & 324 & & 213 & 211 & 2676 \\
\hline Dinobryon sertularia & & & 3 & 15 & & & & \\
\hline Dinobryon sociale & 0.76 & & & & 453 & 672 & & 25 \\
\hline Dinobryon divergens & 0.76 & 0.43 & & & & & & 97 \\
\hline Ochromonas sp. & 1.5 & 2.2 & & & & & 213 & \\
\hline Uroglena americana & 0.030 & 0.047 & & & 2001 & 981 & 535 & 101 \\
\hline Cryptophyta & & & & & & & & \\
\hline Rhodomonas minuta & 1.5 & 2.1 & 45 & 60 & 156 & 471 & 48 & 36 \\
\hline Cryptomonas erosa & 0.35 & 0.38 & & & 12 & 33 & 93 & 36 \\
\hline Dinophyceae & & & & & & & & \\
\hline Ceratium hirundinella & 0.219 & 0.32 & & & 1548 & 1014 & & \\
\hline Gymnodinium spp. & & 0.26 & & & & & & 15 \\
\hline Chlorophyta & & & & & & & & \\
\hline Ankyra judayi & & & & & & 18 & & \\
\hline Chlamydomonas sp. & 0.6 & & 45 & 15 & 144 & 126 & & \\
\hline Monoraphidium spp. & & & & & & & & 48 \\
\hline Mougeotia sp. & 1.04 & 0.45 & 6 & & & & 2 & 39 \\
\hline Oocystis lacustris & & & & & 36 & 15 & & \\
\hline Scenedesmus quadricauda & 0.9 & 0.46 & & 24 & 12 & & & \\
\hline Sphaerocystis schroeteri & 0.13 & 0.24 & 1491 & 981 & & & & 29 \\
\hline Staurastrum paradoxum & & & & & 3 & 6 & & \\
\hline
\end{tabular}

technique, is that a significant amount of labelled ${ }^{14} \mathrm{C}$ should become part of the chlorophyll molecule during the incubation time. This requirement was satisfied by our experiments, as we found a significant correlation $\left(\mathrm{R}^{2}=0.709 ; p<0.000001 ; \mathrm{n}=59\right)$ between the $\mathrm{dpm}$ values of labelled chlorophyll and labelled total algal biomass, measured as POC after filtration. Moreover, the regression line of the two variables $\left(\mathrm{dpm}_{14 \mathrm{Chl}}=\right.$ $\left.0.975 \mathrm{dpm}_{\mathrm{PO} 14 \mathrm{C}}+45.58\right)$ showed a slope very close to 1 and an intercept close to zero, indicating that most of the ${ }^{14} \mathrm{C}$ has been incorporated into chlorophyll.

The growth rates calculated from labelled chlorophyll in each experiment are shown in figure 6: in general, the highest values were recorded in Lago Maggiore, followed by Lake Mergozzo and Lake Varese in that order. We observed a clear relationship with water depth in all three lakes, with the highest growth recorded in the upper part of the water column and the lowest at the limit of the euphotic zone. In Lake
Mergozzo there was a gradual decline of growth from the surface towards the bottom of the illuminated layer; in Lago Maggiore a less distinct pattern emerged, although a deeper growth peak seemed to prevail; in Lake Varese the depth of $25 \%$ of subsurface PAR seems to be optimal for growth. In this lake, both higher and lower light intensities could be limiting or even damaging, as observed in the second experiment, when we measured negative growth just below the surface, because the amount of radioactivity incorporated by the algae was lower than the activity measured in the blank bottle.

Phytoplankton growth rates can also be calculated from productivity values, as ratios between daily productivity and euphotic biomass expressed as carbon (equivalent to a biomass turn-over rate; see Tilzer 1984). Our phytoplankton biovolumes were converted to carbon using a biomass to carbon conversion factor estimated by D. Ruggiu years ago for Lake Mergozzo (algal carbon equal to about $13 \%$ of wet biomass; Sara- 


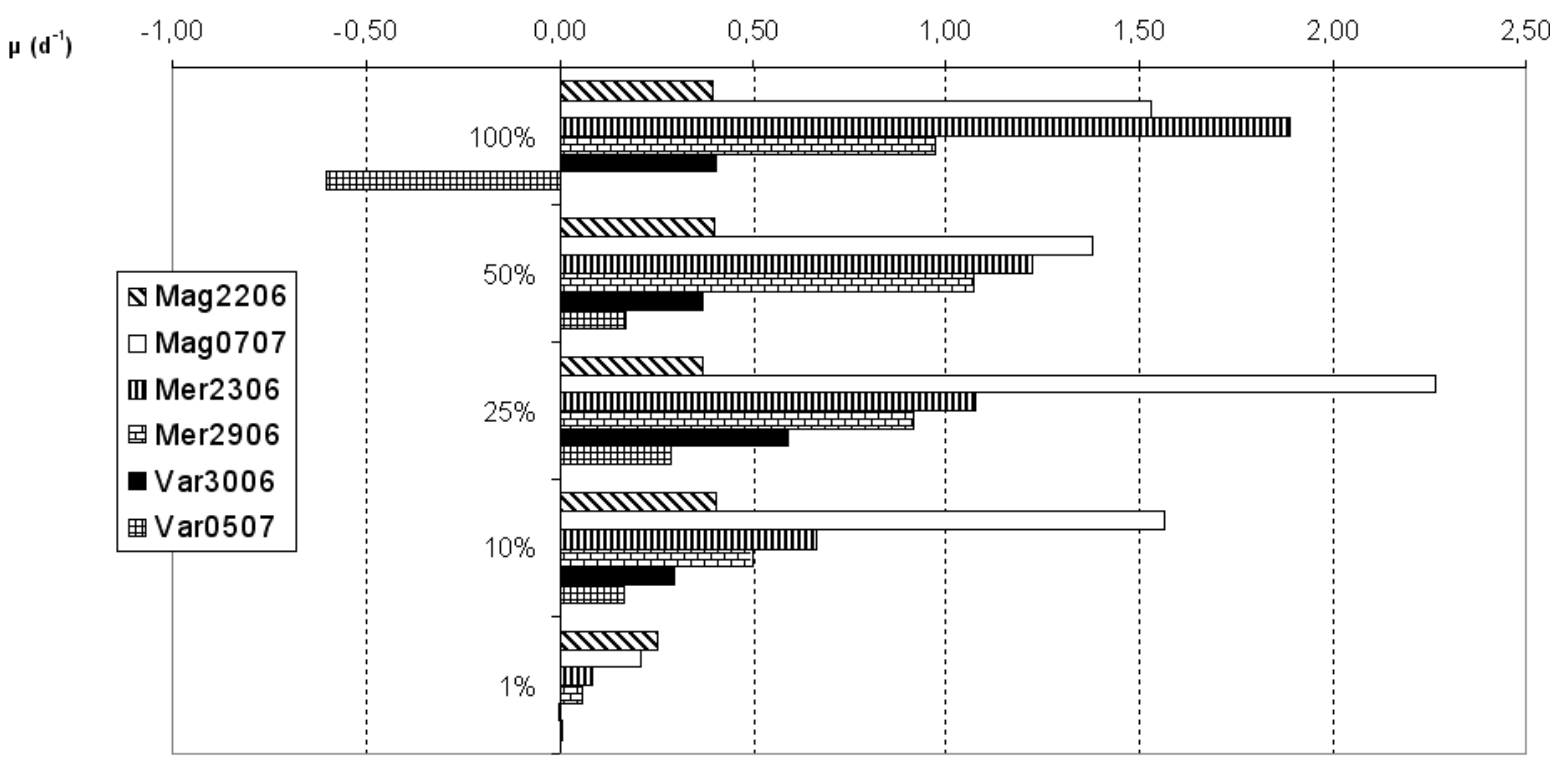

Fig. 6. Comparison of the growth rates measured at different depths (shown as \% of incident light) in the three lakes.

ceni et al. 1978). The growth rates estimated in this way were always lower than the rates calculated from chlorophyll labelling; also, the differences among lakes were less evident (Fig. 7).

Finally, the growth rates at each depth were compared with the average surface area-to-volume ratio (SA/V) of the phytoplankton assemblages present in the euphotic zone of the three lakes at the time of the experiments (Tab. 3): as shown in figure 8 , a positive linear relationship exists between the two variables $(r=$ $0.59 ; p=0.001 ; \mathrm{n}=30$ ). We are aware that a more precise calculation of the $\mathrm{SA} / \mathrm{V}$ ratios, i.e. using direct phytoplankton measurements from each depth, would have been better; however, our findings confirm the general assertion that smaller algae have higher growth rates (Reynolds 1997). In any case, we checked the SA/V ratios published by Reynolds (1984) against the ratios calculated in 2003 for most of the species found in Lago Maggiore (unpublished data), finding a very good correspondence (see Tab. 3).

\section{DISCUSSION AND CONCLUSIONS}

One of the most critical points of the chlorophyll labelling method is the time required for the specific activity of the chlorophyll- $a$ carbon and total algal carbon to become equal. Many studies (see e.g. Riemann et al. 1993 and references therein) demonstrated that the $\mathrm{C}$ specific activity of different intracellular compartments may vary markedly over the diel cycle and does not follow the same temporal pattern for each constituent. Riemann et al. (1993) observed that, in cells grown under a 12:12 L/D cycle, during an incubation lasting only a few hours, the POC specific activities usually exceeded the Chl- $a$ specific activities, although the dis- crepancy was not always very large. The authors attributed this discrepancy to the fact that POC had a higher specific growth rate than chlorophyll. However, this pattern probably characterises cells growing under a constant $12: 12 \mathrm{~L} / \mathrm{D}$ cycle. In this case the specific growth rate of POC during the light period must be very high, to compensate for the respiratory losses of carbon during the dark period, when the inorganic $C$ precursors are used for the synthesis of chlorophyll. The case of algae grown in situ during early summer, when the light period is longer than the dark one, might be different, because the need to compensate for respiratory losses during the night is minimised by the length of the light period available for photosynthesis. This pattern could explain the good relationship between POC and chlorophyll labelling shown by our data, even during short term incubations.

Most of the differences in phytoplankton growth rates recorded among the three basins could be due to the variable species composition, with different morphological characteristics of the individual species. Of these characteristics, the relationship between phytoplankton cell size and growth rate has often been investigated, and there seems to be general agreement about a negative correlation between growth rate and cell size (see Riegman et al. 1993 and references therein). Moreover, it has often been demonstrated that many physiological properties show an allometric relationship with algal cell size (see the review by Capblancq \& Catalan 1994). As a consequence of these relationships, many environmental features, such as light availability, pattern of nutrient supply or grazing pressure, can constrain the composition of a phytoplankton community towards the dominance of large or small sized species. The re- 


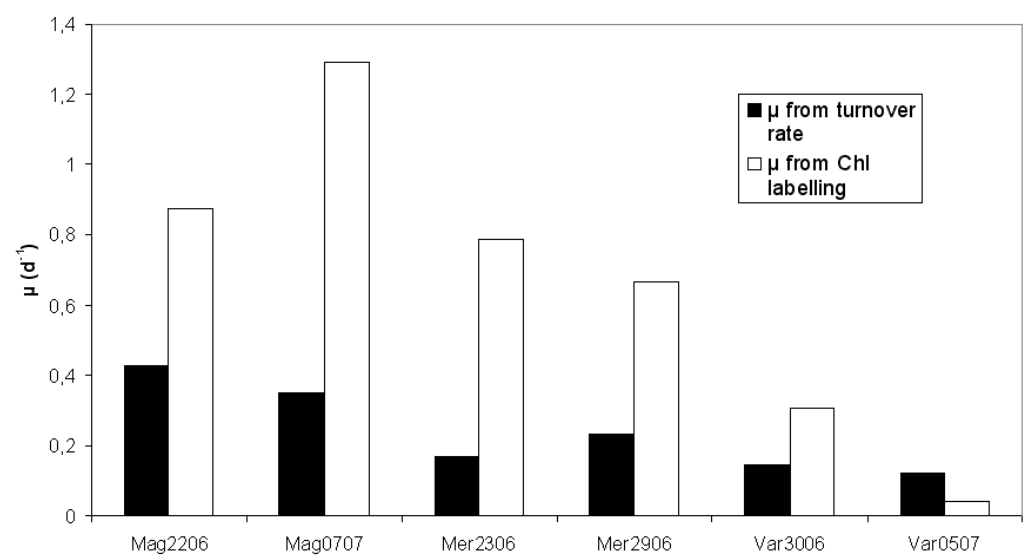

Fig. 7. Comparison of the growth rates estimated from the ${ }^{14} \mathrm{C}$ assimilation (turnover rates) and from chlorophyll labelling.

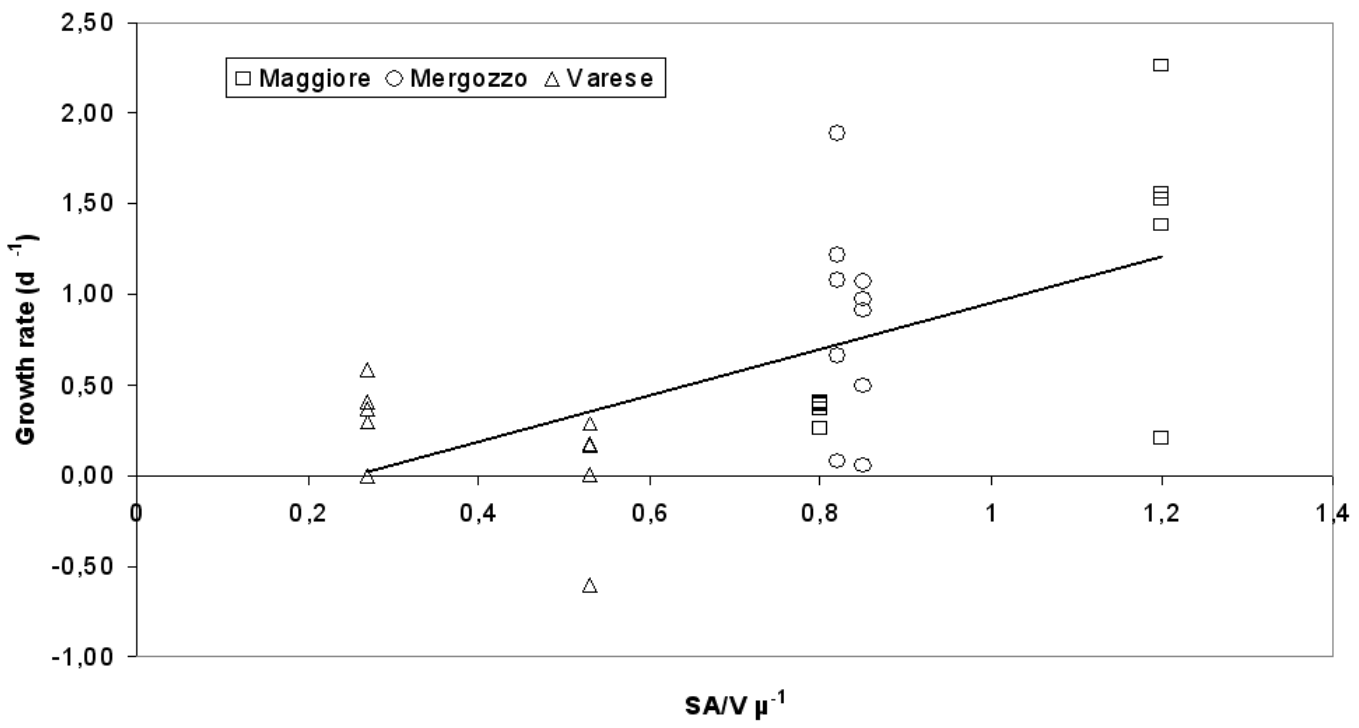

Fig. 8. Relationship between growth rates and mean surface area-to-volume ratio in the three lakes Maggiore (squares), Mergozzo (circles) and Varese (triangles).

sulting community dynamics will ultimately be a complex function of the spectrum of cell size and environmental variability. Because many environmental variables affecting cell physiology are the same as those which define the trophic state of a lake, a link between trophic spectrum and phytoplankton cell morphology can be commonly found and has frequently been described in the literature. Some papers (Watson \& Kalff 1981; Wehr 1993) demonstrated that smaller cells, with their high surface area-to-volume ratio, generally have high nutrient uptake affinities and thus an advantage in lakes with a low nutrient load. For instance, picoplankton is more abundant with decreasing trophic status, because these small algae can have a competitive advantage in nutrient exploitation (Callieri \& Stockner 2000). However, differences found in the average community cell size do not necessarily imply a change in the growth rate: Hein \& Riemann (1995) recorded an increase of the community mean cell volume in enclosures enriched with nitrogen and phosphorus, with no change in the community growth rate. On the other hand, species of similar size can exhibit different trophic preferences and growth rates (e.g. Spijkerman \& Coesel 1998). As a general pattern, the decrease of the average community cell size following a decrease in trophic status is well documented (Edmonson 1991; Ruggiu et al. 1998; Willén 2001) and, together with a general rearrangement of the whole planktonic food web, seems to indicate a change in the pathways of carbon transfer across it.

When these findings are kept in mind, our experimental results confirm that the chlorophyll labelling technique is a promising method for measuring phytoplankton growth rates across the trophic spectrum: the observed correlation between growth rates and average 
surface area-to-volume ratio (Fig. 8) is in agreement with the general relationship linking phytoplankton cell size, growth rate and trophic level.

The two different methods used to estimate phytoplankton growth rates (from ${ }^{14} \mathrm{C}$ incorporation into POC and into chlorophyll) lead to quite different results: in particular, the calculation of the biomass turn-over rate from ${ }^{14} \mathrm{C}$ incorporation into POC seems to be less precise in distinguishing the variable activity of different phytoplankton assemblages. It is quite common to observe large discrepancies between rates of photosynthetic carbon fixation and phytoplankton growth rates (Harris 1986). As pointed out by Capblancq \& Catalan (1994), the main reason for these discrepancies lies in the difficulty of accurately estimating the carbon content of phytoplankton biomass. This estimate can give unreliable values, due to the use of conversion factors and to assuming the weight of cell carbon to be a constant fraction of cell weight.

A comparison of our results with the growth rate values reported in literature is of little interest, because the few papers reporting measures of phytoplankton growth rates deal mostly with cultures, with marine phytoplankton and, in general, with species different from those we found, grown in different environmental conditions. Moreover, as far as we know, no other papers have been published comparing the values of growth rates obtained with chlorophyll labelling with those calculated from biomass turn-over rates. On the other hand, the validity of the labelling technique to measure phytoplankton growth rates under variable ecophysiological conditions has been shown in various in situ experimental studies (Redalje \& Laws 1981; Welschmeyer \& Lorenzen 1984; Goericke \& Welschmeyer 1993, 1998; Hein \& Riemann 1995; Goericke 1998), of which the study by Neale et al. (2001) is the only one carried out in freshwaters.

Although some basic assumptions of the chlorophyll labelling technique are still to be verified (Riemann et al. 1993), the use of this method has yielded realistic results. An overestimation of the specific activity of chlorophyll- $a$ has been reported (Jespersen et al. 1992), ascribable to contamination by non-pigmented lipid compounds (Goericke 1992; Pinckney et al. 1996) or caused by isotope dilution (Riemann et al. 1993). Although a possible overestimation of growth rates cannot be excluded, because of the low radiochemical purity of chlorophyll- $a$ extract, we believe that, since the technical error is similar in all experiments, it will not influence the validity of the following basic conclusions of our research:

- in spite of some drawbacks still affecting the use of the chlorophyll labelling technique, such as the choice of the correct incubation time and the estimation of the chlorophyll specific activity, the method is probably one of the most promising for estimating the growth rates of phytoplankton in situ;
- this method, coupled with information on some algal morphological parameters, such as surface area and/or volume, can provide useful indications about the functional properties of phytoplankton assemblages living in diverse lacustrine environments.

\section{REFERENCES}

Baldi, E. 1949. La situation actuelle de la recherche limnologique après le Congrès de Zurich. Revue suisse Hydrol., 11: 637-649.

Bonomi, G. 1962. Le grandi modificazioni nella fauna macrobentonica del Lago di Varese intervenute nel periodo 1957-1962. Acqua Industriale, 21: 7-10.

Bonomi, G. 1966. Recent modifications and the development of a meromictic-biogenic situation in the Lago di Varese (N. Italy). Verh. int. Ver. Limnol., 16: 245-250.

Calderoni, A., R. Mosello \& R. de Bernardi. 1997. Le indagini sulla evoluzione dei laghi profondi sudalpini svolte dal C.N.R. Istituto Italiano di Idrobiologia. Documenta Ist. ital. Idrobiol., 61: 19-32.

Callieri, C. \& J. Stockner. 2000. Picocyanobacteria success in oligotrophic lakes: fact or fiction? J. Limnol., 59(1): 72-76.

Capblanq, J. \& J. Catalan. 1994. Phytoplankton: which, and how much? In: R. Margalef (Ed.), Limnology Now: A Paradigm of Planetary Problems. Elsevier Science: 9-36.

Edmonson, W.T. 1991. The Uses of Ecology. Lake Washington and beyond. Univ. Washington Press, Seattle: 329 pp.

Goericke, R. 1992. The chlorophyll-labelling method: the radiochemical purity of chlorophyll- $a$ - A response to Jespersen et al., 1992, J. Plankton Res., 14: 1781-1785.

Goericke, R. 1998. Response of phytoplankton community structure and taxon-specific growth rates to seasonally varying physical forcing in the Sargasso Sea off Bermuda. Limnol. Oceanogr., 43: 921-935.

Goericke, R. \& N.A. Welschmeyer. 1993. The chlorophyll-labeling method. Measuring specific rates of chlorophyll- $a$ synthesis in cultures and in the open ocean. Limnol. Oceanogr., 38: 80-95.

Goericke, R. \& N.A. Welschmeyer. 1998. Response of Sargasso Sea phytoplankton biomass, growth rates and primary production to seasonally varying physical forcing. $J$. Plankton Res., 20: 2223-2249.

Guilizzoni, P., G. Bonomi, G. Galanti \& D. Ruggiu. 1983. Relationship between sedimentary pigments and primary production: evidence from core analyses of twelve Italian lakes. Hydrobiologia, 103: 103-106.

Harris, G.P. 1986. Phytoplankton Ecology: Structure, Function and Fluctuations. Chapman \& Hall, London: 384 pp.

Harris, G.P. 1994. Pattern, process and prediction in aquatic ecology. A limnological view of some general ecological problems. Freshwat. Biol., 32: 143-160.

Hein, M. \& B. Riemann. 1995. Nutrient limitation of phytoplankton biomass or growth rate: an experimental approach using marine enclosures. J. Exp. Mar. Biol. Ecol., 188: $167-180$.

Jespersen, A., J. Nielsen, B. Riemann \& M. Søndergaard. 1992. Carbon-specific phytoplankton growth rates: a comparison of methods. J. Plankton Res., 14: 637-648.

Lund, J.W.G., C. Kipling \& E.D. Le Cren. 1958. The inverted microscope method of estimating algal numbers and the statistical basis of estimations by counting. Hydrobiologia, 11: $143-170$.

Manca, M., A. Calderoni \& R. Mosello. 1992. Limnological research in Lago Maggiore: studies on hydrochemistry and plankton. Mem. Ist. ital. Idrobiol., 50: 171-200.

Marchetto, A., A. Lami, S. Musazzi, L. Guzzella, L. Langone, J. Massaferro, R. Bettinetti, G. Morabito \& P. Guilizzoni. 2000. Reconstruction of the recent eutrophication and oligotrophication history of a large sub-alpine lake (Lake 
Maggiore, N. Italy). $8^{\text {th }}$ International Symposium on Paleolimnology. Kingston, Ontario, Canada (poster).

Monti, R. 1929. Limnologia comparata dei laghi insubrici. Verh. int. Ver. Limnol., 4: 462-497.

Mosello, R. \& D. Ruggiu. 1985. Nutrient load, trophic conditions and restoration prospects of Lake Maggiore. Int. Revue ges. Hydrobiol., 70: 63-75.

Mosello, R., P. Panzani, A. Pugnetti \& D. Ruggiu. 1991. An assessment of the hydrochemistry of the eutrophic Lake Varese (N. Italy), coincident with the implementation of the first restoration measures. Mem. Ist. ital. Idrobiol., 49: 99-116.

Neale, P.J., E. Litchman, C. Sobrino, C. Callieri, G. Morabito, V. Montecino, Y. Huot, P. Bossard, C. Lehmann, \& D. Steiner. 2001. Quantifying the response of phytoplankton photosynthesis to ultraviolet radiation: Biological weighting functions versus in situ measurements in two Swiss lakes. Aquat. Sci., 63: 265-285.

Peterson, B.J. 1980. Aquatic primary productivity and the ${ }^{14} \mathrm{C}$ $\mathrm{CO}_{2}$-method. A history of the productivity problem. Ann. Rev. Ecol. Syst., 11: 359-385.

Pinckney, J.L., D.F. Millie, K.E. Howe, H.W. Paerl \& J.P. Hurley. 1996. Flow scintillation counting of ${ }^{14} \mathrm{C}$-labeled microalgal photosynthetic pigments. J. Plankton Res., 18: $1867-1880$

Raven, J.A. \& J.E. Kübler. 2002. New light on the scaling of metabolic rate with the size of algae. J. Phycol., 38: 11-16.

Redalje, D. 1993. The labelled chlorophyll- $a$ technique for determining photoautotrophic carbon specific growth rates and carbon biomass. In: P.F. Kemp, B.F. Sherr, E.B. Sherr \& J.J. Cole (Eds), Handbook of methods in aquatic microbial ecology. Lewis Publishers: 563-578.

Redalje, D. \& E.A. Laws. 1981. A new method for estimating phytoplankton growth rates and carbon biomass. Mar. Biol., 62: 73-79.

Reynolds, C.S. 1984. The ecology of freshwater phytoplankton. Cambridge University Press, Cambridge: $384 \mathrm{pp}$.

Reynolds, C.S. 1997. Vegetation processes in the pelagic: a model for ecosystem theory. Ecology Institute, Oldendorf/Luhe, Germany: $371 \mathrm{pp}$.

Riegman, R., B.R. Kuipers, A.A.M. Noordeloos \& H.J. Witte. 1993. Size-differential control of phytoplankton and the structure of plankton communities. Netherlands Journal of Sea Research, 31: 255-265.

Riemann, B., P. Simonsen \& L. Stensgaard. 1989. The carbon and chlorophyll content of phytoplankton from various nutrient regimes. J. Plankton Res., 11: 1037-1045.

Riemann, B., R. Lignell \& E.A. Laws. 1993. Time-course development of ${ }^{14} \mathrm{C}$ specific activity of chlorophyll- $a$, carbon and protein in algal cultures. Limnol. Oceanogr., 38: 96-111.

Ruggiu, D. 1993. Osservazioni conclusive. Considerazioni generali sull'evoluzione a lungo termine dei popolamenti planctonici. Fitoplancton. In: C.N.R. Istituto Italiano di Idrobiologia, Ricerche sull'evoluzione del Lago Maggiore. Aspetti limnologici. Campagna 1992 e Rapporto quinquennale 1988-1992. Ed. Commissione Internazionale per la protezione delle acque italo-svizzere: 115-116.
Ruggiu, D. \& C. Saraceni. 1972. A statistical study of the distribution and abundance of the bottom fauna of a lake undergoing accelerated eutrophication (Lake Mergozzo, N. Italy). Mem. Ist. ital. Idrobiol., 29: 169-187.

Ruggiu, D., C. Saraceni \& R. Mosello. 1981. Fitoplancton, produzione primaria e caratteristiche chimiche di un lago fortemente eutrofizzato: il Lago di Varese. Mem. Ist. ital. Idrobiol., 39: 47-64.

Ruggiu, D., G. Morabito, P. Panzani \& A. Pugnetti. 1998. Trends and relations among basic phytoplankton characteristics in the course of the long-term oligotrophication of Lake Maggiore (Italy). In: M. Alvarez-Cobelas, C.S. Reynolds, P. Sanchez-Castillo \& J. Kristiansen (Eds), $10^{\text {th }}$ Workshop of the International Association of Phytoplankton Taxonomy and Ecology (IAP), Granada (Spain), 21-29 June 1996. Hydrobiologia, 369-370: 243-257.

Saraceni, C., D. Ruggiu \& M. Nakanishi. 1978. Phytoplankton dynamics, chlorophyll- $a$ and phaeophytin in Lago di Mergozzo (Northern Italy). Mem. Ist. ital. Idrobiol., 36: 215-237.

Spijkerman, E. \& P.F.M. Coesel. 1998. Ecophysiological characteristics of two planktonic desmid species originating from trophically different lakes. In: M. Alvarez-Cobelas, C.S. Reynolds, P. Sanchez-Castillo \& J. Kristiansen (Eds), $10^{\text {th }}$ Workshop of the International Association of Phytoplankton Taxonomy and Ecology (IAP), Granada (Spain), 21-29 June 1996. Hydrobiologia, 369-370: 109-116.

Steeman-Nielsen, E. 1952. The use of radioactive carbon $\left({ }^{14} \mathrm{C}\right)$ for measuring organic production in the sea. J. Cons. Perm. Int. Explor. Mer, 18: 117-140.

Tilzer, M. 1984. Estimation of phytoplankton loss rates from daily photosynthetic rates and observed biomass changes in Lake Constance. J. Plankton Res., 6: 309-324.

Tonolli, V. \& G. Bonomi. 1965. Stato biologico del Lago di Varese nelle situazioni passate e presente. In: L'inquinamento del Lago di Varese: indagini, rilevamenti, proposte. Amm.ne Prov.le Varese: 89-108.

Vollenweider, R. 1965. Materiali ed idee per una idrochimica delle acque insubriche. Mem. Ist. ital. Idrobiol., 19: 213-286.

Watson, S. \& J. Kalff. 1981. Relationships between nannoplankton and lake trophic status. Can. J. Fish. aquat. Sci., 38: 960-967.

Wehr, J.D. 1993. Effects of experimental manipulations of light and phosphorus supply on competition among picoplankton and nanoplankton in an oligotrophic lake. Can. J. Fish. aquat. Sci., 50: 936-945.

Welschmeyer, N.A. \& C.J. Lorenzen. 1984. Carbon-14 labeling of phytoplankton carbon and chlorophyll- $a$ carbon: Determination of specific growth rates. Limnol. Oceanogr., 29: 135-145.

Willén, E. 2001. Phytoplankton and water quality characterization: experiences from the Swedish large lakes Mälaren, Hjälmaren, Vättern and Vänern. Ambio, 30: 529-537.

Williams, P.J. LeB. 1993. Chemical and tracer methods of measuring plankton production: what do they in fact measure. ICES Mar. Sci. Symp., 197: 20-36.

Zutshi, D. 1976. Phytoplankton productivity, algal dynamics and trophic status of Lake Mergozzo (Northern Italy). Mem. Ist. ital. Idrobiol., 33: 221-256. 